\title{
Long-term effects of an iron heater and Äspö groundwater on smectite clays: Chemical and hydromechanical results from the in situ alternative buffer material (ABM) test package 2
}

\author{
SIRPA KUMPULAINEN ${ }^{1, *}$, LEENA KIVIRANTA ${ }^{1}$ AND PETRI KORKEAKOSKI ${ }^{2}$ \\ ${ }^{1}$ B+Tech Oy, Laulukuja 4, 00420 Helsinki, Finland \\ ${ }^{2}$ Posiva Oy, Olkiluoto, 27160 Eurajoki, Finland
}

(Received 31 May 2015; revised 12 December 2015; Guest Editor: Reiner Dohrmann)

\begin{abstract}
Smectite-rich clays are to be used in nuclear repositories for sealing in the radioactive waste. As the radioactive decay produces heat it may affect the chemical, physical and hydromechanical properties of the clay components in the repository. An 'alternative buffer material' (ABM) experiment is a Svensk Kärnbränslehantering $\mathrm{AB}$ (SKB)-led in situ heating test placed in boreholes in the Äspö tunnel (Sweden). The $2^{\text {nd }}$ ABM package was dismantled in April 2013, after $6.5 \mathrm{y}$ of equilibration with Äspö groundwater and $5 \mathrm{y}$ of heating. The objective was to investigate the long-term effects of the iron heater and Äspö groundwater on four of 31 compacted blocks made of MX-80, Deponit CaN and Friedland clays.

Compared to the starting materials, major changes in the exchangeable cation populations were observed. Within horizontal profiles, water-soluble sulfate, $\mathrm{Ca}, \mathrm{K}$ and $\mathrm{Mg}$ increased; poorly crystalline Fe oxide contents decreased; total $\mathrm{Mg}, \mathrm{Ca}$ and $\mathrm{S}$ increased; and a decrease in the amounts of total $\mathrm{Na}$ and $\mathrm{K}$ away from the host rock towards the heater was observed. At the boundary with the heater, an increase in the total $\mathrm{Fe}$ content, decreases in total $\mathrm{Si}$ and $\mathrm{Al}$ contents, precipitation of gypsum and anhydrite, dissolution of cristobalite and feldspars, and indications of the formation of trioctahedral clay minerals were observed. A decrease in swelling pressure for the Friedland clay (in drill-cored samples) was recorded which was recovered after grinding and recompaction. No effects of hydraulic conductivity were found, after $6.5 \mathrm{y}$ of reaction time, in the subsurface of any of materials studied.
\end{abstract}

KEYWORDS: chemistry, mineralogy, nuclear waste disposal, in situ tests, Fe-bentonite interaction, swelling pressure.

The chemistry and physical properties of clay materials used in nuclear waste repository buffer systems are modified through interactions with surrounding groundwater, by the degradation products of structural components consisting of $\mathrm{Fe}, \mathrm{Cu}$ or cement, or by heat produced by the fuel canister. In the alternative buffer

*E-mail: sirpa.kumpulainen@btech.fi

DOI: 10.1180/claymin.2016.051.2.02 material (ABM) experiment, six packages (ABM1-6) containing steel heaters surrounded by stacks of compacted bentonite rings of various clay materials were placed in boreholes in the Äspö hard-rock laboratory at a depth of $-450 \mathrm{~m}$. The package surfaces were sealed with layers of concrete. To increase the water distribution along the test package, the slot between the buffer package and the rock was filled with sand (Eng et al., 2007). Heating of ABM1 started simultaneously with saturation whereas heating of the 
ABM2 package was started only after the bentonite was fully saturated.

The $1^{\text {st }}$ ABM package was dismantled in 2009 after $2.5 \mathrm{y}$ of heating, of which $1.5 \mathrm{y}$ was at the maximum temperature $\left(130^{\circ} \mathrm{C}\right)$. The chemical changes found included a general change in the exchangeable cation composition (Kumpulainen \& Kiviranta, 2011; Svensson et al., 2011; Dohrmann et al., 2013) and accumulation of water-soluble sulfate (Muurinen, 2010; Kumpulainen \& Kiviranta, 2011; Svensson et al., 2011) and Mg (Svensson et al., 2011; Kaufhold et al., 2013) in horizontal profiles towards the iron heater. In addition, a decrease in swelling pressure was observed in core-drilled samples in some materials but no difference in hydraulic conductivity was recorded between samples from the field experiment and the corresponding reference materials (Kumpulainen \& Kiviranta, 2011; Svensson et al., 2011). In contact with the heater or close to it, $\mathrm{Fe}$ accumulated in bentonite (Kumpulainen \& Kiviranta, 2011; Svensson et al., 2011). Dissolution of carbonates, the formation of trioctahedral minerals/domains, the precipitation of siderite and anhydrite, and dissolution of clinoptilolite and cristobalite were found only in certain bentonites (Svensson et al., 2011; Kaufhold et al., 2013).

The $2^{\text {nd }} A B M$ package was dismantled in 2013 after equilibrating for $\sim 6.5 \mathrm{y}$ and after $5 \mathrm{y}$ of heating, of which $\sim 3-4 \mathrm{y}$ was at the maximum temperature $\left(130^{\circ} \mathrm{C}\right)$. Details of the experimental design and dismantling procedure were presented by Svensk Kärnbränslehantering AB (2014) and Svensson et al. (2011). The scope of the present study was to examine long-term changes in the ABM2 samples due to $\mathrm{Fe}$-bentonite interaction and hydrothermal alteration and compare the ABM2 results with the results from the ABM1 package and reference samples. For comparison, the same methods were applied as in the previous studies (Kumpulainen \& Kiviranta, 2010, 2011; Muurinen, 2010).

\section{MATERIALS}

Upon dismantling of the ABM2 package, some of the blocks were found to be more fragile than in the ABM1 package and thus could not be sampled intact. The blocks selected for the present study, namely block 2 (MX-80), block 4 (Friedland clay), block 5 (Deponit$\mathrm{CaN}$ ) and block 6 (MX-80) were located side by side in the lower part of the ABM2 parcel (Fig. 1a). Samples from blocks 4, 5 and 6, were taken for analyses at various distances along the horizontal profiles (B4Fr: 0-3 mm, 3-20 mm, 20-37 mm, 54-74 $\mathrm{mm}$ and 89
$94 \mathrm{~mm}$; B5Dep: 0-3 mm, 3-21 mm, 21-31 mm, 44$60 \mathrm{~mm}$ and $76-92 \mathrm{~mm}$; B6Mx: 0-4 mm, 4-21 mm, 21-35 mm, 49-63 mm and 77-97 mm) (Fig. 1b). In addition, heater contact samples (B4Fr 0-1 mm, B5Dep 0-1 mm, B6Mx 0-1 mm) for mineralogical analyses were scraped from other pieces of the blocks studied.

Sampling was by means of a knife, band saw, or by core-drilling. Drill-cored samples were used as received for swelling-pressure and hydraulic-conductivity tests (Fig. 1c). Bulk samples were dried at $60^{\circ} \mathrm{C}$ and crushed in an agate mortar using a pestle. Recompacted samples for swelling pressure and hydraulic conductivity measurements that were taken from the same distance from the heater as the coredrilled samples, were crushed gently and recompacted to the same density as the corresponding core-drilled samples. Clay fractions were separated from wet, non-ground bulk samples of B6Mx 4-21 mm, B5Dep 3-21 mm, and B4Fr 3-20 mm by suspending the bulk sample in deionized water, adding $\mathrm{NaCl}$ salt, followed by centrifugation, and decantation of the clear supernatant. Excess salts were then washed off by repeated addition of deionized water and centrifugation, and finally by dialysis (Spectrapore 3, 3500 MWCO pore size dialysis membrane). Then, the coarse fraction $(>0.5 \mu \mathrm{m})$ was separated by sedimentation (with the assistance of centrifugation) and the supernatant was removed carefully using a pipette. Salt treatment, washing, and dialysis were repeated twice thereafter for the supernatant. The $<0.5 \mu \mathrm{m}$ fraction was selected in order to remove accessory minerals from clay minerals more efficiently. Some of the Na-converted clay suspension was exchanged to the $\mathrm{Mg}$-form for XRD analysis, and the remainder was dried at $60^{\circ} \mathrm{C}$, ground with an oscillating mill to $\sim 10 \mu \mathrm{m}$, and analysed for CEC and chemical composition.

\section{METHODS}

\section{Chemical composition}

Water extraction was performed to obtain information about the composition of solutes and soluble salts in the bentonite. The ground bulk sample was dispersed in deionized water (solid:liquid ratio of $1: 100)$ by mixing with a magnetic stirrer for $24 \mathrm{~h}$. The solids were then separated from the supernatant by centrifugation (1100 rpm, $90 \mathrm{~min})$, and filtration through $0.45 \mu \mathrm{m}$ and $0.2 \mu \mathrm{m}$ pore size filters. Part of the supernatant was further filtered through a $0.1 \mu \mathrm{m}$ pore size filter for inductively coupled plasma-atomic 
a

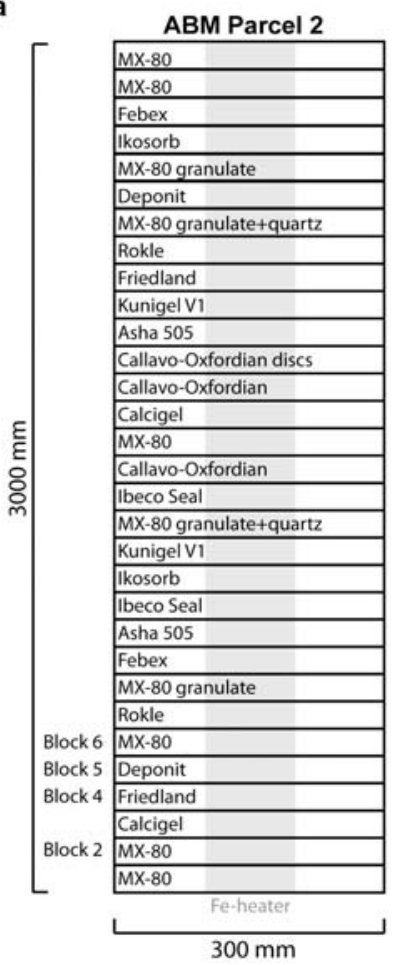

b
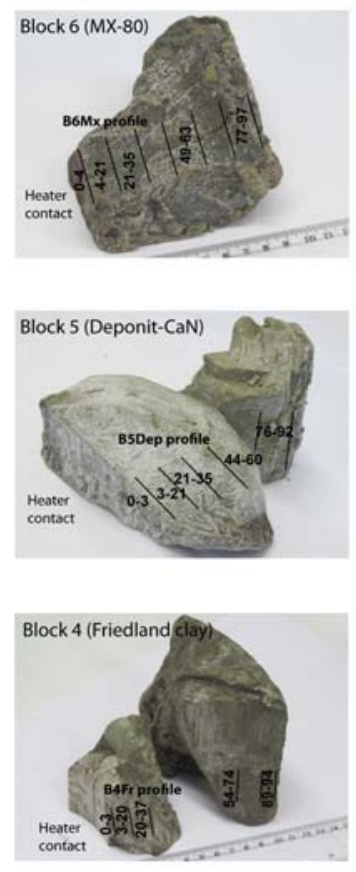

c

Analysis scheme

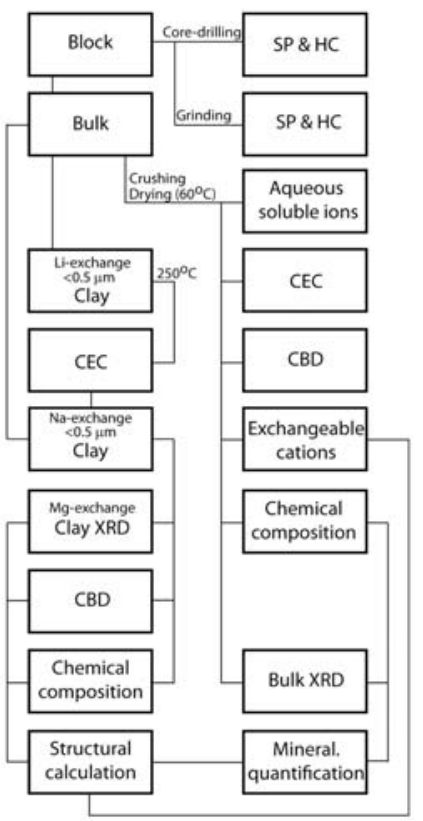

FIG. 1. (a) ABM parcel 2 experimental setup. (b) Photos of samples of the blocks on which the majority of analyses were done. Sampling and sample distance from the heater contact are given in mm. (c) Analysis scheme. Abbreviations: SP \& $\mathrm{HC}=$ swelling pressure and hydraulic conductivity, $\mathrm{CEC}=$ cation exchange capacity, $\mathrm{CBD}=$ citrate-bicarbonatedithionite extraction, $\mathrm{XRD}=\mathrm{X}$-ray diffraction.

emission spectroscopy (ICP-AES) analyses. The concentrations of $\mathrm{Na}, \mathrm{K}, \mathrm{Mg}, \mathrm{Ca}, \mathrm{Al}, \mathrm{Si}$ and Fe were determined from the supernatant using ICP-AES and the concentrations of $\mathrm{Cl}$ and $\mathrm{SO}_{4}$ by ion chromatography at Labtium Oy, Finland. The results were adjusted against adsorbed water content (determined gravimetrically at $105^{\circ} \mathrm{C}$ ).

Exchangeable cations were determined using $\mathrm{NH}_{4} \mathrm{Cl}$ in $80 \%$ ethanol (Belyayeva, 1967; Jackson, 1975). $0.8 \mathrm{~g}$ of ground bulk material was dispersed in $\sim 2 \mathrm{~mL}$ of $0.15 \mathrm{M} \mathrm{NH}_{4} \mathrm{Cl}$ in $80 \%$ ethanol. The suspensions were shaken on a rocking platform for $120 \mathrm{~min}$, centrifuged, and the supernatant was decanted into a volumetric flask. The extraction was repeated twice with $10 \mathrm{~mL}$ of extraction solution to reach the total volume of $40 \mathrm{~mL}$. The extract was filtered through a $0.2 \mu \mathrm{m}$ pore-size filter, ethanol was evaporated and the extract was diluted to $50 \mathrm{~mL}$ using deionized water. The amounts of dissolved $\mathrm{Ca}, \mathrm{K}, \mathrm{Fe}, \mathrm{Na}$ and $\mathrm{Mg}$ were determined using ICP-AES at Labtium Oy. The results were adjusted against adsorbed water content (determined gravimetrically at $105^{\circ} \mathrm{C}$ ) and were reported as equivalent charges $/ \mathrm{kg}$ of dry weight.

Cation exchange capacity (CEC) was measured with the $\mathrm{Cu}$ (II)-triethylenetetramine method (Meier \& Kahr, 1999; Ammann et al., 2005; Dohrmann et al., 2012a, b). $200 \mathrm{mg}$ of air-dried ground bulk sample were dispersed in $25 \mathrm{~mL}$ of deionized water. $10 \mathrm{~mL}$ of $0.015 \mathrm{M} \mathrm{Cu}(\mathrm{II})$-triethylenetetramine solution was added and allowed to react for $30 \mathrm{~min}$ on a rocking platform. The suspension was centrifuged and the supernatant was collected. The $\mathrm{Cu}(\mathrm{II})$-triethylenetetramine concentration in the supernatant was measured at $620 \mathrm{~nm}$ using a Thermo Scientific Genesys 10S UV-Vis spectrophotometer. The CEC was calculated on the basis of the uptake of $\mathrm{Cu}$-complex by the clay. All CEC determinations were done in duplicate and reported as mean values. The mean standard deviation of duplicate analyses was $0.01 \mathrm{eq} / \mathrm{kg}$. The results were adjusted against adsorbed water content 
(determined gravimetrically at $105^{\circ} \mathrm{C}$ ) and were reported as equivalent charges $/ \mathrm{kg}$ of dry weight.

Bulk chemical compositions and speciation of $\mathrm{C}$ and $\mathrm{S}$ of the bulk material and of the Na-homoionic $<0.5$ $\mu \mathrm{m}$ fraction of the bentonite were determined at ACME Analytical Laboratories, Canada. $\mathrm{Si}, \mathrm{Al}, \mathrm{Fe}, \mathrm{Mg}, \mathrm{Ca}$, $\mathrm{Na}, \mathrm{K}, \mathrm{Ti}, \mathrm{P}, \mathrm{Mn}, \mathrm{Cr}, \mathrm{Ba}, \mathrm{Ni}, \mathrm{Sr}, \mathrm{Zr}, \mathrm{Y}, \mathrm{Nb}$ and $\mathrm{Sc}$ were determined by ICP emission or mass spectroscopy using standard techniques for silicate analysis $\left(\mathrm{LiBO}_{2} /\right.$ $\mathrm{Li}_{2} \mathrm{~B}_{4} \mathrm{O}$ fusion followed by nitric-acid digestion). Loss on ignition (LOI) was determined as the difference in weight of the dried (at $105^{\circ} \mathrm{C}$ ) and the ignited sample (at $1000^{\circ} \mathrm{C}$ ). Total carbon and sulfur were determined by evolved gas analysis (EGA) by combustion of the samples in a LECO furnace, equipped with IR detectors. Organic carbon was determined as $\mathrm{CO}_{2}$ evolved after treatment of a sub-sample with hot $15 \%$ $\mathrm{HCl}$. Sulfate was determined on separate samples preignited at $550^{\circ} \mathrm{C}$. The concentrations of sulfide-S and inorganic $\mathrm{C}$ were estimated by subtracting the concentrations of sulfate-S and organic $\mathrm{C}$ from the total concentrations of $\mathrm{S}$ and $\mathrm{C}$, respectively. The results from the ABM2 experiment were compared with those in reference samples that have been calculated from Kumpulainen \& Kiviranta (2010) by adjusting the adsorbed-water contents. Standard deviation of duplicate analyses of $\mathrm{ABM} 2$ samples were 0.09 wt. $\%$ for $\mathrm{SiO}_{2}, 0.07$ wt. $\%$ for $\mathrm{Al}_{2} \mathrm{O}_{3}$ and total-C, 0.02 for $\mathrm{Fe}_{2} \mathrm{O}_{3}, 0.01$ wt. $\%$ for $\mathrm{Na}_{2} \mathrm{O}$ and total $\mathrm{S}$, and $<0.01$ wt. $\%$ for $\mathrm{MgO}, \mathrm{CaO}, \mathrm{K}_{2} \mathrm{O}, \mathrm{TiO}_{2}$, sulfate-S and organic-C.

Citrate-bicarbonate-dithionite extraction (CBD) was used to determine the amount of poorly crystalline $\mathrm{Fe}$ oxides in the bulk sample and in the purified clay fraction. $0.5 \mathrm{~g}$ of ground material was placed in a centrifuge tube. $20 \mathrm{~mL}$ of $0.3 \mathrm{M} \mathrm{Na}$-citrate solution and $2.5 \mathrm{~mL}$ of $1 \mathrm{M} \mathrm{NaHCO}_{3}$ solution were added, the tube was placed in a water bath, heated at $80^{\circ} \mathrm{C}$ and $0.17 \mathrm{~g}$ of $\mathrm{Na}_{2} \mathrm{~S}_{2} \mathrm{O}_{4}$ was added and the mixture was stirred constantly for $1 \mathrm{~min}$ with a glass rod and then occasionally for $5 \mathrm{~min}$. Addition of sodium dithionite and mixing were repeated twice, and the mixture was allowed to cool. A mixture of saturated $\mathrm{NaCl}$ solution and deionized water was added to induce flocculation, and the suspension was centrifuged. The supernatant was collected and filtered through $0.45 \mu \mathrm{m}$ pore-size filter. The residue was then washed with saturated $\mathrm{NaCl}$ solution and deionized water, followed by centrifugation and filtration. The filtered supernatant solution was diluted to $100 \mathrm{~mL}$ with deionized water. Concentrations of dissolved $\mathrm{Fe}, \mathrm{Si}, \mathrm{Al}$ and $\mathrm{Mg}$ were determined by ICP-AES analysis at Labtium Oy,
Finland. The results were adjusted against adsorbed water content (determined gravimetrically at $105^{\circ} \mathrm{C}$ ).

\section{MINERALOGICAL METHODS}

For mineralogical analyses, the bulk samples were ground in an agate pestle and mortar using acetone. Approximately $10 \mathrm{mg}$ of the ground bulk materials were mixed with acetone on a glass slide and placed in a desiccator that contained saturated $\mathrm{Mg}\left(\mathrm{NO}_{3}\right)_{2}$ solution to achieve standard relative humidity (54\% $\mathrm{RH}$ at $2^{\circ} \mathrm{C}$ ), for at least 5 days. Subsequently the samples were transferred one by one to a rotating sample holder and scanned from 2 to $70^{\circ} 2 \theta$ with a Bruker D8 Advance X-ray diffractometer equipped with a $\mathrm{Cu}$ tube and Lynxeye $\mathrm{XE}$ detector. The goniometer radius was $280.0 \mathrm{~mm}$. Samples were scanned using a fixed slit, a voltage of $40 \mathrm{kV}$ and current of $40 \mathrm{~mA}$, and a $0.5 \mathrm{~s}$ step-time with $0.01^{\circ} 2 \theta$ counting step at the Geological Survey of Finland.

The clay mineralogy was determined by X-ray diffraction (XRD) of samples at a distance of $\sim 3-21 \mathrm{~mm}$ from the heater, using oriented mounts prepared from purified, $\mathrm{Mg}$-saturated $<0.5 \mu \mathrm{m}$ clay fractions. The filter-membrane peel-off technique was used for preparation of the mounts (Drever, 1973; Moore \& Reynolds, 1989). A concentrated suspension was vacuum filtered onto a $0.45 \mu \mathrm{m}$ pore-size cellulose filter and transferred to a glass slide. Sample mounts were dried in air, kept at least overnight in a desiccator that contained saturated $\mathrm{Mg}\left(\mathrm{NO}_{3}\right)_{2}$ solution, and scanned from 2 to $35^{\circ} 2 \theta$ with $0.2 \mathrm{~s}$ step-time with $0.02^{\circ} 2 \theta$ counting step at the Geological Survey of Finland. Subsequently they were placed in a desiccator containing EG and put into an oven at $60^{\circ} \mathrm{C}$ for $20 \mathrm{~h}$. The EGsolvated mounts were scanned from 2 to $35^{\circ} 2 \theta$ with $0.2 \mathrm{~s}$ step-time and $0.02^{\circ} 2 \theta$ counting step to identify smectites. Then, mounts were placed in the furnace for $2 \mathrm{~h}$ at $550^{\circ} \mathrm{C}$, and scanned from 2 to $35^{\circ} 2 \theta$ to identify kaolinite.

The bulk mineralogical composition was determined from randomly oriented XRD patterns of bulk samples using a full-profile Rietveld refinement in the Siroquant software version 3 that includes a clay package for quantifying clay minerals with unknown crystal structures such as montmorillonite. However, as Friedland clay contains mixed-layer illite-smectite (I-S) which cannot be modeled directly using Siroquant, it was treated in the analysis as two separate mineral phases: smectite and illite. The same mineral phases were included in quantifications of all samples of the horizontal profiles as well as the reference samples. After subtraction of the background, refinement was 
performed in subsequent stages until no major improvement in pattern fit was achieved. Instrument zero, phase scales, half-widths, unit-cell dimensions, and preferred orientation were refined. Mineralogical composition was validated by comparison of the calculated chemical composition with the observed chemical data. Smectite and illite-mica contents were adjusted assuming that all $\mathrm{K}$ (from chemical composition of purified clay fraction) was bound to illite and that the illite-smectite ratio was constant in all samples of the horizontal profile. The smectite structural formula was calculated from the chemical composition of purified $<0.5 \mu \mathrm{m}$ clay fractions for MX-80 and Deponit CaN according to Newman \& Brown (1987), after extracting CBD-extractable $\mathrm{Fe}$, and illite content (assuming ideal composition), and taking into account exchangeable cation results. The accessory mineral contents from mineralogical analysis were compared with the calculated mineral contents assuming that all $\mathrm{Ti}$ was bound to anatase, all inorganic carbon was bound to calcite (MX-80 and Deponit $\mathrm{CaN}$ ) or siderite (Friedland clay), all sulfate was bound to gypsum, and that the remaining sulfur was in pyrite.

The decrease in CEC due to $\mathrm{Li}$ uptake was performed to identify the charge location in the smectite structure (octahedral vs. tetrahedral). Firstly, to separate the clay, the bulk samples taken $\sim 20$ $37 \mathrm{~mm}$ from the heater were dispersed in $3 \mathrm{M} \mathrm{LiCl}$, stirred for $24 \mathrm{~h}$, washed with deionized water, and $<0.5 \mu \mathrm{m}$ fractions were separated by sedimentation. The clay fractions were treated once with $3 \mathrm{M} \mathrm{LiCl}$ solution, and washed with deionized water until incipient dispersion and excess salts were then removed by dialysis (Spectrapore 3, 3500 MWCO pore-size dialysis membrane). Samples were dried at $60^{\circ} \mathrm{C}$, ground with an oscillating mill and agate mortar, placed in a porcelain crucible and heated at $250^{\circ} \mathrm{C}$ for $24 \mathrm{~h}$. After heating, the samples were ground again before CEC determination (see the description for CEC determination above).

\section{Hydromechanical tests}

Swelling pressure and hydraulic conductivity were measured first by placing core-drilled samples into fixed-volume swelling-pressure cells, between porous frits, piston and force transducer. Pre-stress loads of $\sim 10 \%$ of expected equilibrium swelling pressure were established on each sample prior to saturation. De-aired salt solution $(10 \mathrm{~g} / \mathrm{L} \mathrm{NaCl})$ was used as the saturating solution, which was first allowed to flow slowly through the bottom circuit of the cells, and thereafter through both the top and bottom circuits of the cells. Axial force due to sample swelling was logged until it was stabilized, and after that hydraulic conductivity measurement was started by increasing the water pressure (using a pressure panel) into one of the cell-bottom circuits to a load pressure of $\sim 50-350 \mathrm{kN}$, which did not exceed half of the measured swelling pressure in any of the samples. One end of a clear tubing of known diameter was attached to one of the cell-top circuit ports with the other end remaining open to the atmosphere. The volume of fluid permeating through the sample and out of the cell-top circuit was measured as a function of time. Subsequently the saturated sample was removed from the swelling-pressure cell, the dimensions were measured, the water content was determined gravimetrically at $105^{\circ} \mathrm{C}$ and the bulk density was determined gravimetrically by immersing the sample in paraffin oil. After the density had been determined, neighbouring samples (taken from the same distance as the cored samples) were ground, compressed to the same density, and swelling pressure and hydraulic conductivity measurements were repeated.

\section{RESULTS}

\section{Water-soluble ions}

Analysis of water-soluble ions showed accumulation of water-soluble sulfate, $\mathrm{Ca}, \mathrm{Mg}$ and $\mathrm{K}$ in horizontal profiles near the heater (Fig. 2). An opposing, decreasing trend towards the heater was recorded for water-soluble chloride contents. In B5Dep and $\mathrm{B} 6 \mathrm{Mx}$ profiles, the maximum for water-soluble $\mathrm{K}$, $\mathrm{Ca}, \mathrm{Mg}$ and $\mathrm{SO}_{4}$ was found at the heater contact. In the $\mathrm{B} 4 \mathrm{Fr}$ profile, the maximum for water-soluble $\mathrm{K}, \mathrm{Ca}$, $\mathrm{Mg}$ and $\mathrm{SO}_{4}$ was observed at $\sim 10-30 \mathrm{~mm}$ from the heater. In the B6Mx profile, the water-soluble $\mathrm{Si}$ and $\mathrm{Fe}$ contents increased at the cool end of the profile.

Comparison of water-soluble $\mathrm{SO}_{4}^{2-}$ and $\mathrm{Cl}^{-}$contents in ABM2 samples with the reference samples (Muurinen, 2010; Svensson et al., 2011) showed that the $\mathrm{SO}_{4}^{2-}$ was redistributed in the ABM2 samples compared to the reference samples whereas $\mathrm{Cl}^{-}$ contents increased in ABM2 samples compared to the reference samples (Fig. 2).

\section{CBD-extractable Fe, $\mathrm{Al}$, Si and $\mathrm{Mg}$}

Citrate-bicarbonate-dithionite-extractable $\quad \mathrm{Fe}$ decreased steadily in horizontal profiles B4Fr and B5Dep towards the heater (Fig. 3). In contrast, CBDextractable $\mathrm{Mg}$ increased towards the heater in all the 

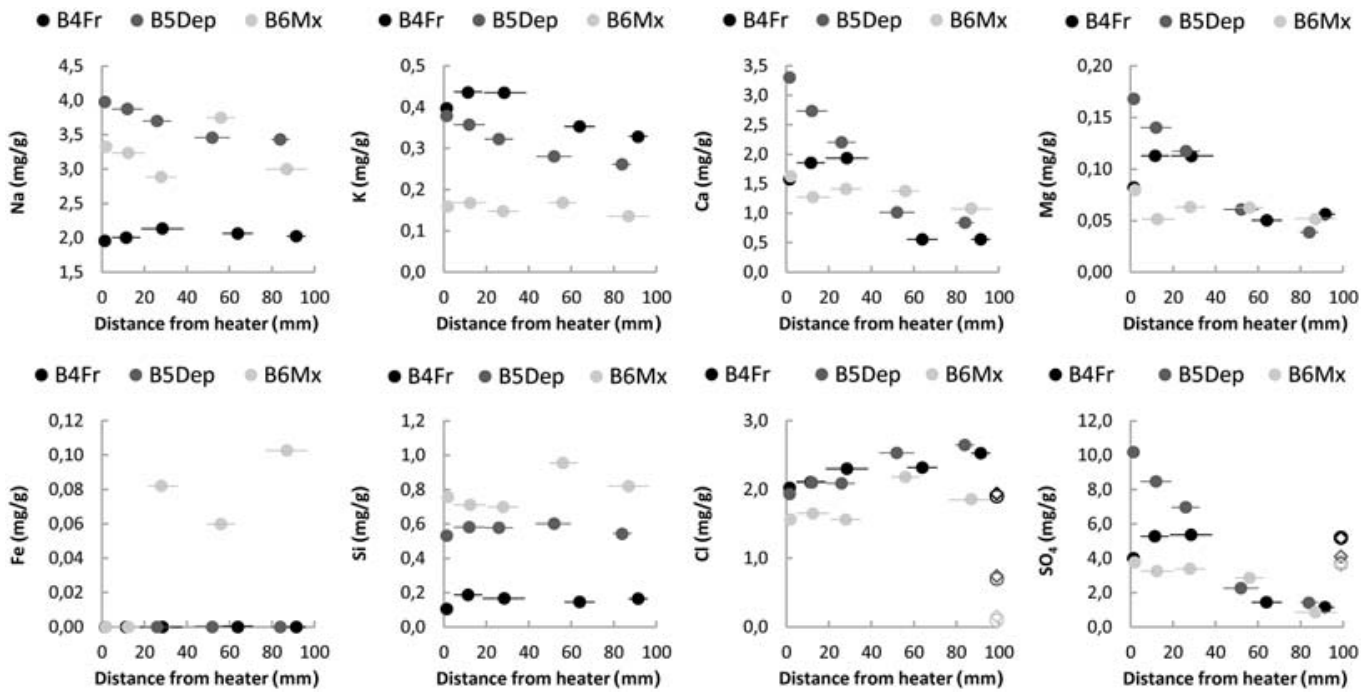

FIG. 2. Aqueous soluble ions as a function of the distance from the heater. Open symbols shown for $\mathrm{Cl}$ and $\mathrm{SO}_{4}$ are reference levels from Muurinen (2010) (circles) and Svensson et al. (2011) (diamonds).

materials studied (Fig. 3). In the B4Fr profile, the CBD-extractable Al contents also increased slightly towards the heater. There was also a clear decreasing trend in CBD-extractable $\mathrm{Si}$ in B5Dep horizontal profile towards the heater (Fig. 3).

The amount of CBD-extractable $\mathrm{Fe}_{2} \mathrm{O}_{3}$ and $\mathrm{SiO}_{2}$ was smaller in ABM2 Friedland clay and Deponit $\mathrm{CaN}$ bulk samples than in reference bulk samples reported by Kumpulainen \& Kiviranta (2011) and Svensson et al. (2011). The amount of CBD-extractable $\mathrm{MgO}$ in all ABM2 samples was significantly smaller than the reference samples (Fig. 3).

\section{Exchangeable cations and CEC}

In general, exchangeable cation contents, the sum of exchangeable cations and CEC were comparable in all samples of the horizontal profiles, with few exceptions.
The amounts of exchangeable $\mathrm{Mg}$, especially in $\mathrm{B} 6 \mathrm{Mx}$, and exchangeable $\mathrm{Ca}$ (and thus also the sum of exchangeable cations) appeared to be slightly higher at or in the vicinity of the heater (Fig. 4). Further, in the B5Dep horizontal profile, the CEC appeared to increase slightly from $0.83 \mathrm{eq} / \mathrm{kg}$ at the rock contact to $0.87 \mathrm{eq} / \mathrm{kg}$ at the heater contact (Fig. 4).

Comparing the ABM2 results with the reference samples (Kumpulainen \& Kiviranta 2010), saturation of exchangeable cation sites had changed dramatically in all ABM2 samples. The changes were similar in all materials: increase in $\mathrm{Ca}$, and decrease in $\mathrm{Na}, \mathrm{Mg}$ and $\mathrm{K}$. The CEC of ABM2 samples did not change compared to the reference samples. The sum of exchangeable cations in the ABM2 samples was $\sim 0.05-0.2 \mathrm{eq} / \mathrm{kg}$ smaller than the reference samples in all the materials studied, but it was also (in MX-80 and Deponit $\mathrm{CaN}$ ) $\sim 0.1 \mathrm{eq} / \mathrm{kg}$ smaller than the measured CEC.
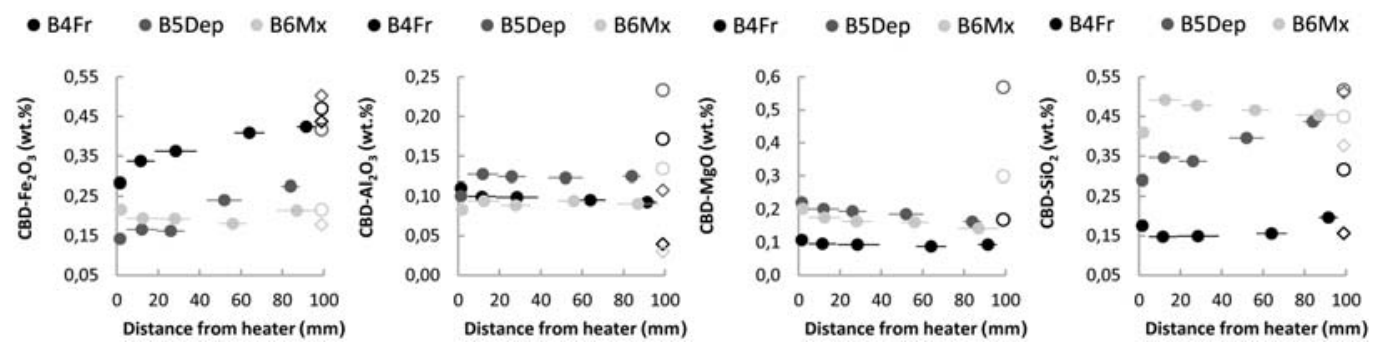

FIG. 3. CBD-extractable $\mathrm{Al}_{2} \mathrm{O}_{3}, \mathrm{Fe}_{2} \mathrm{O}_{3}, \mathrm{MgO}$ and $\mathrm{SiO}_{2}$ as a function of the distance from the heater. Open symbols are reference levels from Kumpulainen \& Kiviranta (2011) (circles) and Svensson et al. (2011) (diamonds). 

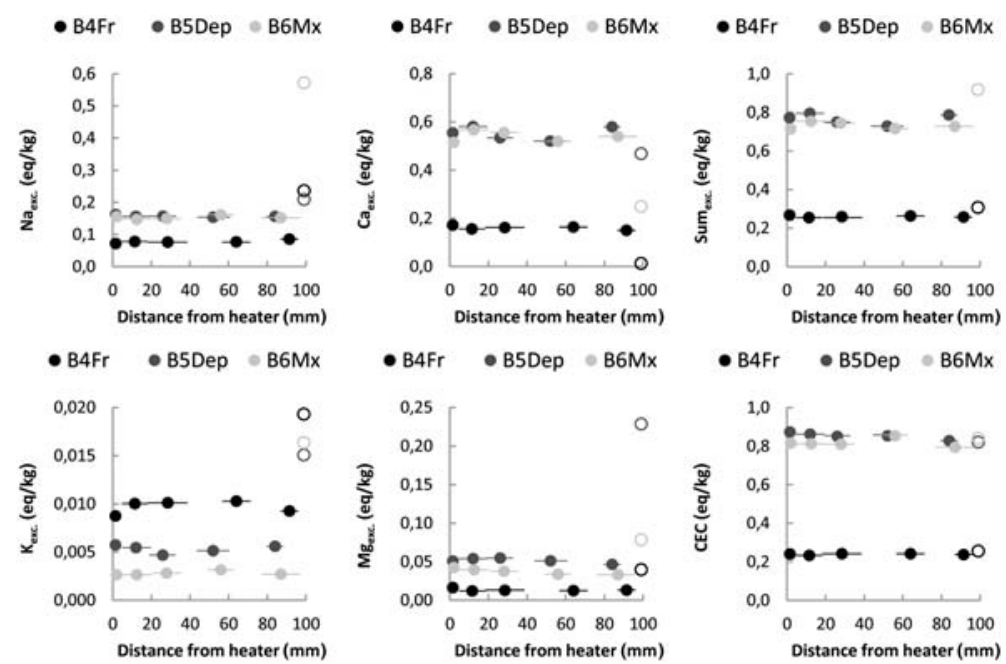

Fig. 4. Exchangeable cations and CEC values (as eq $/ \mathrm{kg}$ of dry $\left(105^{\circ} \mathrm{C}\right)$ mass) as a function of the distance from the heater. Open symbols are reference levels from Kumpulainen \& Kiviranta (2011) (circles).

\section{Total chemical compositions}

Loss on ignition (LOI) increased in the horizontal profiles in the vicinity of the heater in B6Mx (from 12.4 to $13.5 \mathrm{wt} . \%$ ) and B5Dep (from 15.3 to $16.0 \mathrm{wt} . \%$ ), but not in Friedland clay (Fig. 5). Increase in LOI originated from the increase in total $\mathrm{C}$ and total $\mathrm{S}$. The increase in inorganic carbon, indicating precipitation of carbonates, was noted in the horizontal profile of B4Fr towards the heater and in the sample in contact with the heater from the B5Dep profile. On the other hand, an increase in organic carbon content explained the increase in total carbon in the B5Dep profile, and in the heater-contact sample of B6Mx (Fig. 5).

All of the materials studied showed a general increasing trend in total $\mathrm{S}$ towards the heater. This increase was due to a general increase in sulfate towards the heater in B5Dep (0.51-0.63 wt.\%) and B6Mx (0.15-0.26 wt.\%). Horizontal profile B4Fr had a sulfate maximum (0.44 wt. $\%$ ) at a distance of $20-37 \mathrm{~mm}$ from the heater, and the B5Dep profile had an apparent sulfidic $\mathrm{S}$ maximum at the same distance (Fig. 5).

The Al content decreased in the heater-contact samples in all materials, whereas $\mathrm{Si}$ decreased not only in the contact sample but also close to the contact (distance of 3-21 mm). The opposite trend was observed in horizontal profiles for $\mathrm{Mg}$ contents, i.e. an increasing trend towards the heater. The $\mathrm{Ca}$ content also increased slightly in horizontal profiles towards the heater (Fig. 5). The opposite was noted for $\mathrm{Na}$ and $\mathrm{K}$ contents, which decreased slightly in horizontal profiles towards the heater. The only exceptions were that in the heater-contact sample of B4Fr, the Na content increased compared to the samples remaining in the profile, and that no trend in $\mathrm{K}$ content of profile B6Mx was found.

The total amount of Fe had increased in the heatercontact samples (within $4 \mathrm{~mm}$ ) of all materials. Bulk samples of ABM2 of all studied materials appeared to have gained $\mathrm{CaO}$, and organic carbon, and lost $\mathrm{SiO}_{2}$, $\mathrm{MgO}, \mathrm{Na}_{2} \mathrm{O}$ and inorganic carbon, when compared to the levels in the reference samples (Kumpulainen \& Kiviranta, 2010) (Fig. 5).

\section{Bulk mineralogy}

X-ray diffraction patterns and associated Siroquant analysis of ABM2 samples showed that the samples of the B6Mx profile consist of smectite, illite-mica, quartz, cristobalite, plagioclase, K-feldspar, calcite, gypsum, pyrite and anatase; the samples of the B5Dep profile contain smectite, illite-mica, quartz, cristobalite, tridymite/opal, plagioclase, K-feldspar, calcite, dolomite, gypsum, pyrite and anatase and the samples of the B4Fr profile contain mixed-layer I-S, kaolinite, quartz, K-feldspar, siderite, gypsum, pyrite and anatase, with only minor deviations. In the B6Mx profile, the cristobalite content appeared to have diminished in samples closest to the heater (within 1 and $4 \mathrm{~mm}$, Fig. 6, Table 1). In addition, in some samples (distances of $0-1 \mathrm{~mm}$ and $49-63 \mathrm{~mm}$ from the heater) gypsum was more pronounced compared to other samples in the profile (Fig. 6). In the B5Dep 

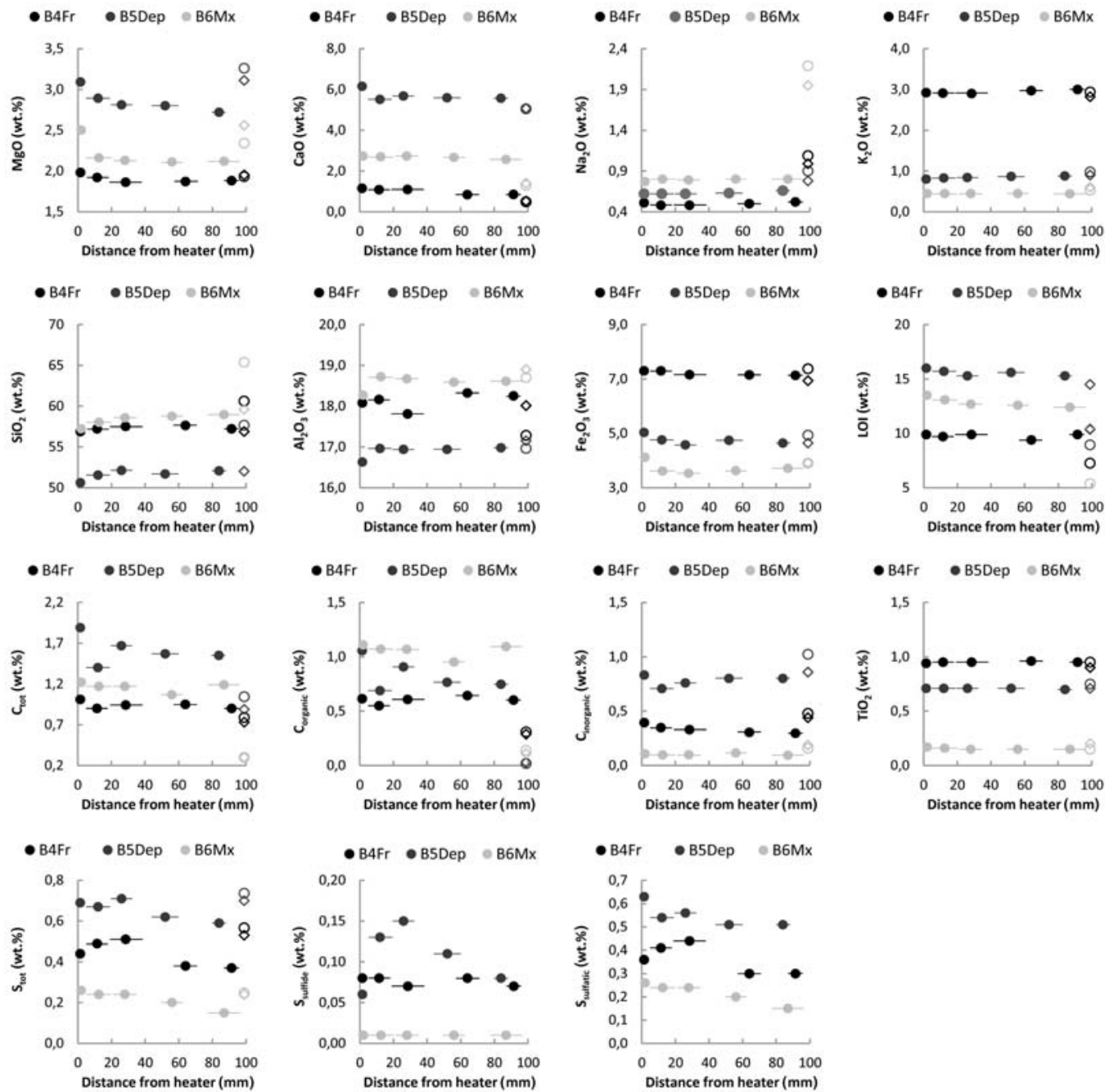

FIG. 5. Chemical compositions in horizontal profiles of the Friedland clay, Deponit $\mathrm{CaN}$ and MX-80 as a function of the distance from the heater. The open symbols are reference levels from Kumpulainen \& Kiviranta (2010) (circles) and Svensson et al. (2011) (diamonds).

profile, samples taken from the zone of contact with the heater (between 1 and $3 \mathrm{~mm}$ ) contained gypsum, and a sample within $3 \mathrm{~mm}$ of the heater also contained anhydrite. In the B4Fr profile, samples taken from the heater contact zone contained gypsum (Fig. 6). In samples closest to the heater (within $1 \mathrm{~mm}$ ) there was also an indication of a decrease in feldspar contents in all materials (Fig. 6, Table 1).

Comparison of mineralogical composition results from Siroquant analysis (Table 1) with compositions of reference samples showed that overall there were no major changes in the bulk mineralogy.

\section{Clay mineralogy}

The positions of $d_{001}$ reflection in bulk samples, indicative of the type of clay mineral and of the type of exchangeable cations and hydration, were approximately the same in all samples of the horizontal profiles of all materials (Fig. 6). Compared to the references, the position of the smectite $d_{001}$ line in bulk samples, shifted from 12.6 to $14.6 \AA$ in MX-80, from 14.3 to $14.9 \AA$ in Deponit CaN, and from 12.7 to $14.2 \AA$ in Friedland clay (Fig. 6).

The position of the clay minerals $d_{060}$ reflection, which is indicative of site occupancy in the octahedral sheet and of the type of clay mineral, was the same in 

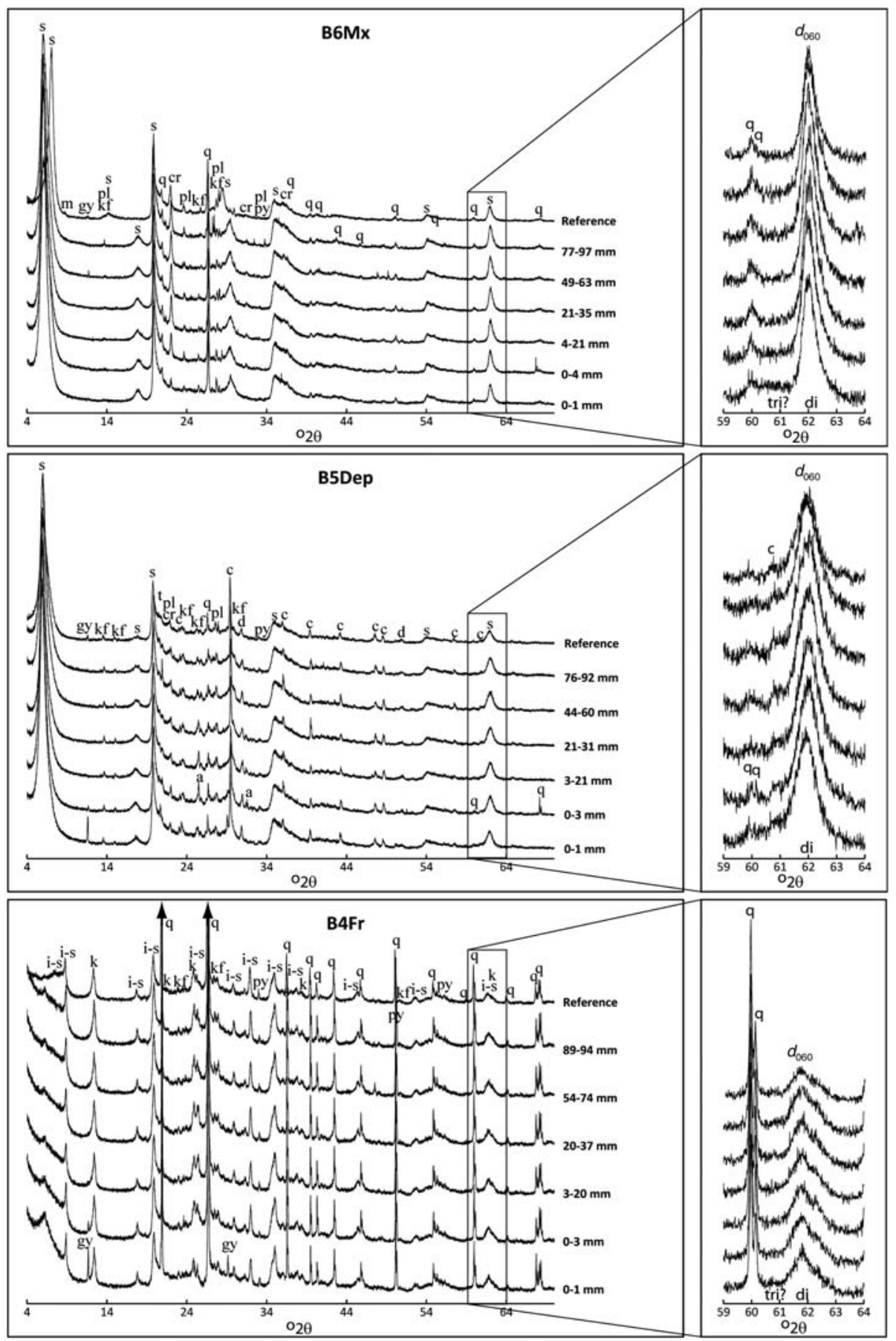

FIG. 6. XRD patterns of randomly oriented bulk samples, the minerals identified, and an enlargement of the clay minerals $d_{060}$ region. Abbreviations: $\mathrm{s}=$ smectite, $\mathrm{i}-\mathrm{s}=$ interstratified illite-smectite, $\mathrm{m}=$ illite/mica, $\mathrm{k}=\mathrm{kaolinite}$, $\mathrm{q}=$ quartz, $\mathrm{pl}=$ plagioclase, $\mathrm{kf}=\mathrm{K}$-feldspar, $\mathrm{gy}=$ gypsum, $\mathrm{a}=$ anhydrite, $\mathrm{c}=$ calcite, $\mathrm{d}=$ dolomite, $\mathrm{cr}=$ cristobalite, $\mathrm{t}=$ tridymite, $\mathrm{py}=$ pyrite, tri $=$ trioctahedral, $\mathrm{di}=$ dioctahedral . 


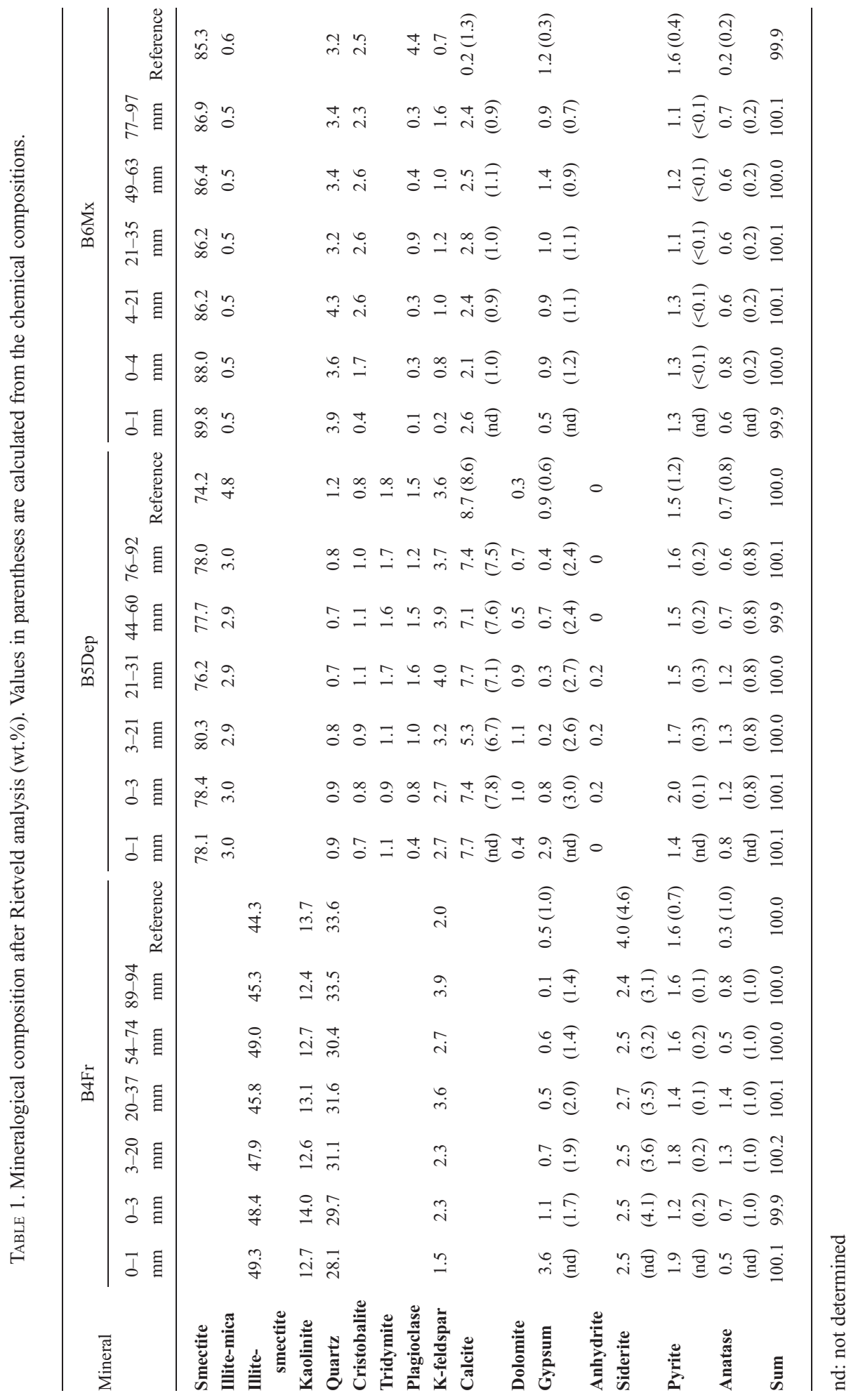



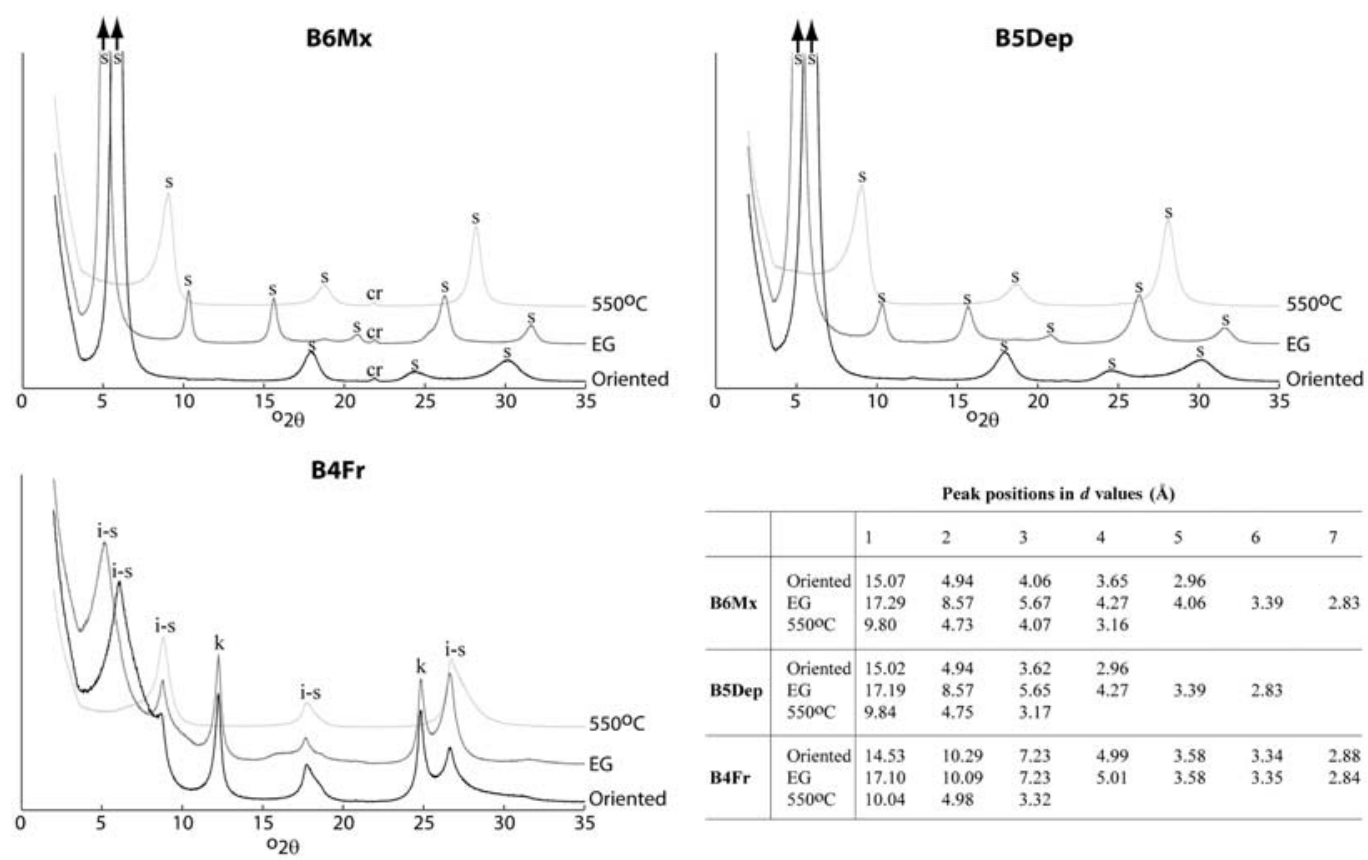

\begin{tabular}{|c|c|c|c|c|c|c|c|c|}
\hline & & & Peak & sitions & $t$ value & & & \\
\hline & & 1 & 2 & 3 & 4 & 5 & 6 & 7 \\
\hline & Oriented & 15.07 & 4.94 & 4.06 & 3.65 & 2.96 & & \\
\hline B6Mx & & 17.29 & 8.57 & 5.67 & 4.27 & 4.06 & 3.39 & 2.83 \\
\hline & $550^{\circ} \mathrm{C}$ & 9.80 & 4.73 & 4.07 & 3.16 & & & \\
\hline & Oriented & 15.02 & 4.94 & 3.62 & 2.96 & & & \\
\hline B5Dep & & 17.19 & 8.57 & 5.65 & 4.27 & 3.39 & 2.83 & \\
\hline & $550^{\circ} \mathrm{C}$ & 9.84 & 4.75 & 3.17 & & & & \\
\hline & Oriented & 14.53 & 10.29 & 7.23 & 4.99 & 3.58 & 3.34 & 2.88 \\
\hline $\mathrm{B} 4 \mathrm{Fr}$ & & 17.10 & 10.09 & 7.23 & 5.01 & 3.58 & 3.35 & 2.84 \\
\hline & $550^{\circ} \mathrm{C}$ & 10.04 & 4.98 & 3.32 & & & & \\
\hline
\end{tabular}

FIG. 7. XRD patterns, the minerals identified and peak positions for oriented clay fractions separated from samples at distances of 4-21 mm (B6Mx), 3-21 mm (B5Dep) and 3-20 mm (B4Fr) from the iron heater. Abbreviations: $\mathrm{s}=$ smectite, $\mathrm{m}=$ illite/mica, $\mathrm{i}-\mathrm{s}=$ interstratified illite-smectite, $\mathrm{k}=$ kaolinite, $\mathrm{cr}=$ cristobalite, oriented $=$ air dry sample, $\mathrm{EG}=$ ethylene glycol-solvated sample, $550^{\circ} \mathrm{C}=$ heat-treated sample.

all samples of the horizontal profiles and located for MX-80 and Deponit CaN at $1.50 \AA$, and for Friedland clay at $1.49-1.50 \AA$ (interstratified I-S and kaolinite). The position of the $d_{060}$ line was also the same as in reference samples (Fig. 6). There was a suggestion of the appearance of trioctahedral phases in samples taken $0-1 \mathrm{~mm}$ from the iron heater, however, as indicated by a small hump between 1.54 and $1.52 \AA\left(60-61^{\circ} 2 \theta\right)$ in the MX-80 and Friedland clays (Fig. 6).

The purified clay fraction of MX-80 contained trace amounts of accessory cristobalite in addition to smectite; the clay fraction of Deponit CaN contained only smectite, and the clay fraction of the Friedland contained both mixed-layer I-S and abundant kaolinite (Fig. 7). All clay minerals in clay fractions were the same as in the purified clay fractions of reference samples (Kumpulainen \& Kiviranta, 2010).

The CEC measurements after $\mathrm{Li}$ saturation and heating at $250^{\circ} \mathrm{C}$ showed a minor increase in the tetrahedral charge of smectite (from $23 \%$ in the reference clay fraction after Kumpulainen \& Kiviranta, 2010 , to $28 \%$ in clay fraction of the present study) in a sample of Deponit CaN 21$31 \mathrm{~mm}$ from the heater, a minor decrease in a sample of
Friedland clay $20-37 \mathrm{~mm}$ from the heater (from $51 \%$ in reference clay fraction after Kumpulainen \& Kiviranta, 2010 to $45 \%$ in clay fraction of the present study), but no change in the sample of MX-80 $21-35 \mathrm{~mm}$ from the heater (from $16 \%$ in the reference clay fraction after Kumpulainen \& Kiviranta, 2010, to $15 \%$ in the clay fraction in the present study).

The structural formulae of smectites calculated from the chemical compositions of the purified $<0.5 \mu \mathrm{m}$ clay fractions, CBD extractions and initial exchangeable cation compositions (Fig. 1c) determined from samples $\sim 3-21 \mathrm{~mm}$ from the heater were as follows:

$$
\begin{aligned}
& \text { Deponit CaN: } \mathrm{Ca}_{0.29} \mathrm{Mg}_{0.03} \mathrm{Na}_{0.16} \mathrm{Al}_{2.96} \\
& \mathrm{Fe}_{0.46} \mathrm{Mg}_{0.60} \mathrm{Al}_{0.24} \mathrm{Si}_{7.76} \mathrm{O}_{20}(\mathrm{OH})_{4} \\
& \text { MX-80: } \mathrm{Ca}_{0.26} \mathrm{Mg}_{0.02} \mathrm{Na}_{0.13} \mathrm{Al}_{3.12} \mathrm{Fe}_{0.38} \\
& \mathrm{Mg}_{0.48} \mathrm{Al}_{0.12} \mathrm{Si}_{7.88} \mathrm{O}_{20}(\mathrm{OH})_{4}
\end{aligned}
$$

The beidellite contents calculated from structural formulae were $30 \%$ for Deponit $\mathrm{CaN}$ and $17 \%$ for MX-80, comparable with the results from a quantitative Greene-Kelly test: $28 \%$ and $15 \%$, respectively.

Because the chemical compositions and XRD analyses were made on the same $<0.5 \mu \mathrm{m}$ batch, and 
the only identified source of error in the calculation of the smectite structural formulae was the tiny amount of $\mathrm{SiO}_{2}$ polymorphs in the sample of MX-80, appearing as a tiny hump at $d$ spacing $=4.04 \AA$. Comparison of smectite structural compositions of MX- 80 and Deponit $\mathrm{CaN}$ from $\mathrm{ABM} 2$ with structural compositions of smectites of similar origin (Kiviranta \& Kumpulainen, 2011) showed a small increase in tetrahedral charge (increase in tetrahedral $\mathrm{Al}$ content from 0.05 moles to 0.12 moles and from 0.10 moles to 0.24 moles, respectively), but no change in total charge. These changes are rather small and are considered to be within the precision of the method.

Calculated CEC values for smectites of ABM2 samples were in line with the measured CEC values of the clay fraction for samples from B6Mx $(0.92 \mathrm{eq} / \mathrm{kg}$ and $0.95 \mathrm{eq} / \mathrm{kg}$, respectively) and B5Dep $(1.06 \mathrm{eq} / \mathrm{kg}$ and $1.03 \mathrm{eq} / \mathrm{kg}$, respectively).

\section{Hydromechanical tests}

Core-drilled samples of Friedland clay in ABM2 showed a $\sim 0.5-2 \mathrm{MPa}$ decrease in a swelling pressure (Fig. 8) compared to the reference samples (Kumpulainen \& Kiviranta, 2011). The decrease was larger for samples taken closer to the heater. After grinding and recompaction of samples, however, the swelling pressure was recovered. For the Deponit CaN and MX-80 samples, the swelling pressure did not decrease, at least by not more than in the ABM1 samples (Kumpulainen \& Kiviranta 2011; Svensson et al., 2011). No changes in hydraulic conductivities were observed in any of the samples tested.

\section{DISCUSSION}

\section{Groundwater-bentonite interaction}

The major changes in exchangeable cations as well as in $\mathrm{Na}, \mathrm{K}, \mathrm{Ca}$ and $\mathrm{Mg}$ total contents compared to reference samples might originate from interactions, namely saturation and cation exchange, with Äspö groundwater. In general, the changes in exchangeable cation populations in ABM2 samples were clearly more pronounced than observed previously (Kumpulainen \& Kiviranta, 2011; Dohrmann et al., 2013). Dohrmann et al. (2013) found that the exchangeable cation compositions in ABM parcel 1 varied considerably between the blocks, and that blocks located in the upper part of the parcel were richer in $\mathrm{Ca}$ than blocks located in the bottom part of the parcel. Those authors also noted that the influence of neighbouring blocks on cation compositions was much less important than the position within the test parcel. Similar variation in exchangeable cation compositions between different blocks of material was not observed in the present study probably because the blocks selected were located side by side, and because the equilibration time was longer $(6.5 \mathrm{y}$ in $\mathrm{ABM} 2$ vs. $2.5 \mathrm{y}$ in ABM1).

In $\mathrm{ABM} 2$, the exchangeable cation population in Friedland clay $(27-33 \% \mathrm{Na}, 3-4 \% \mathrm{~K}, 5-6 \% \mathrm{Mg}$ and $58-64 \% \mathrm{Ca}$ ) differed slightly from MX-80 and Deponit CaN (19-22\% Na, 0-1\% K, 5-7\% Mg and $71-75 \% \mathrm{Ca}$ ), resulting either from lack of equilibrium in exchangeable cation reactions, or from differences in the affinity of exchangeable cations towards mineral surfaces between different materials. The latter explanation is considered more probable because the mineralogical composition of Friedland clay is rather different from those of Deponit CaN and MX-80.

\section{$\mathrm{Fe}$-bentonite interaction}

Iron in the heater influenced the clays studied very locally. The total amount of iron did not increase in the $\mathrm{B} 6 \mathrm{Mx}$, B5Dep, or $\mathrm{B} 4 \mathrm{Fr}$ profiles in the ABM2 experiment, except for some minor accumulation in the B6Mx and B5Dep profiles directly at the contact with the iron heater, within $3 \mathrm{~mm}$. A decrease in CBDextractable $\mathrm{Fe}$ appears in the horizontal profiles of Deponit $\mathrm{CaN}$ and Friedland clay towards the steel heater, however. Furthermore, the amount of CBDextractable Fe was smaller in ABM2 Deponit $\mathrm{CaN}$ and Friedland clay samples than in the reference samples or in ABM1 samples (Kumpulainen \& Kiviranta, 2011). Thus, Fe previously bound in poorly crystalline $\mathrm{Fe}$ oxides was reduced, the crystallinity of Fe oxides might have improved due to thermal effects, or the Fe phases were altered (e.g. precipitation of maghemite or magnetite both of which are less soluble in CBD). Such changes are thought to result not from $\mathrm{Fe}-$ bentonite interaction, but rather from other reactions, e.g. from thermal effects. Neoformed Fe-bearing mineral phases and increase in existing Fe-bearing mineral phases, or changes in the smectite compositions (in terms of Fe content) were not observed. As the sampling and sample preparations were performed in oxidative conditions, conclusions on Fe speciation could not be given. Furthermore, as the sampling was restricted by the amount of material needed for the analyses, mineralogical changes may have occurred at the contact (see Svensson, 2015, for example) but could 


\section{$B 6 M x \& B 2 M x$}
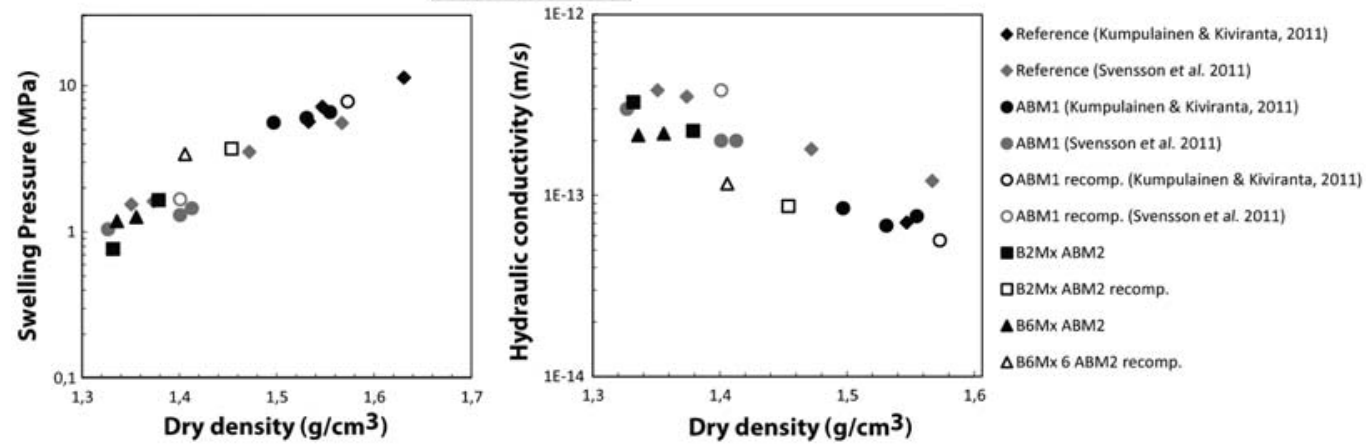

\section{B5Dep}
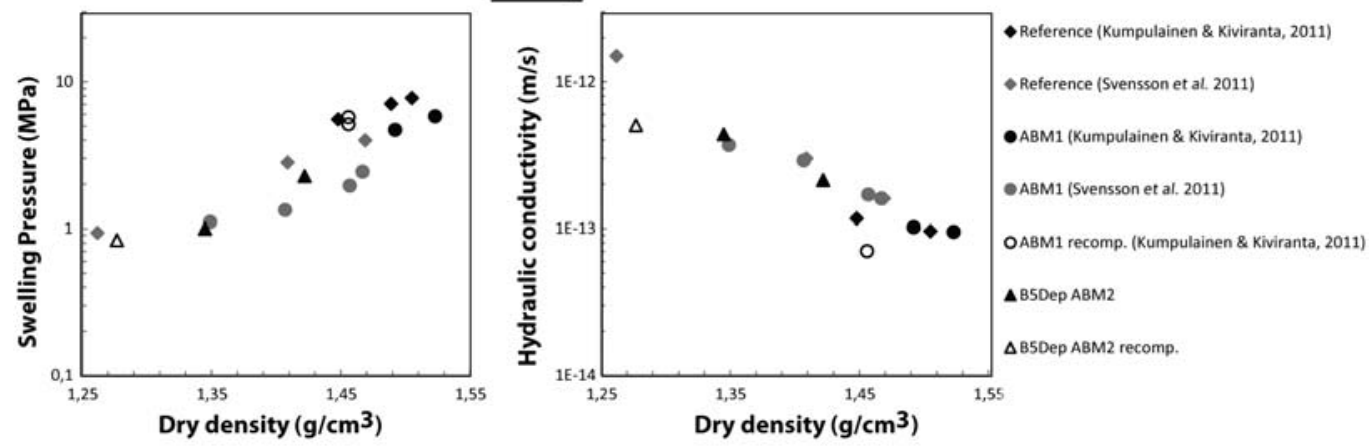

\section{B4Fr}
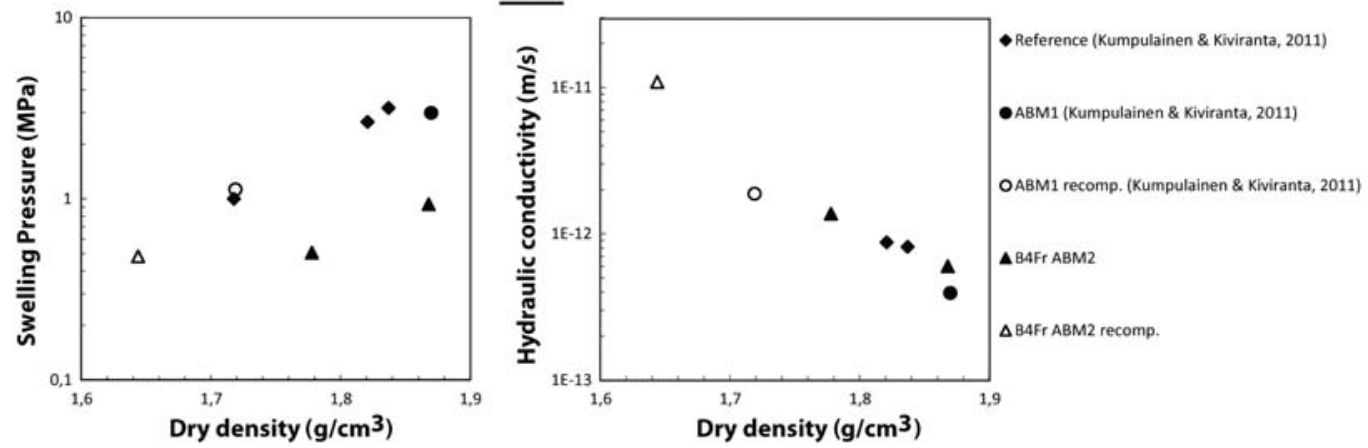

FIG. 8. Swelling pressure and hydraulic conductivity of drill-cored samples (filled symbols) and recompacted samples (open symbols) from the present study (ABM2) as a function of dry density. Reference samples (diamonds) and samples from previous studies (ABM1, circles) are shown for comparison with results in the present study (ABM2).

not be detected in the present study due to dilution effects.

\section{Alteration of the clay materials due to thermal effects}

Elevated temperature and prevailing temperature gradients were important reasons for many of the changes observed. Overall, the observed changes in ABM2 were similar to those seen in other long-term in situ heating tests such as LOT (Karnland et al., 2009), TBT (Åkesson et al., 2012) or Prototype (Olsson et al., 2013; Dohrmann \& Kaufhold, 2014).

Water extractions showed that sulfate salts had accumulated at the heater contact (Deponit $\mathrm{CaN}$ and MX-80) or at distances of 4-35 mm from the heater 
(Friedland clay). Salts consisted mostly of $\mathrm{Ca}$ and $\mathrm{SO}_{4}$, but small amounts of $\mathrm{Mg}$ and $\mathrm{K}$ were assumed to have coprecipitated with $\mathrm{CaSO}_{4}$. The amounts of watersoluble $\mathrm{Cl}$ in Deponit CaN, Friedland clay, and MX-80 in ABM2 test were greater than those observed by Muurinen (2010) and Svensson et al. (2011) from the ABM1 experiment, but the amounts of water-soluble $\mathrm{SO}_{4}$ in these materials of the ABM2 test were generally smaller than observed in the ABM1 test by Muurinen (2010) and Svensson et al. (2011). Thus, soluble salts were considered to have been redistributed within the blocks rather than accumulated towards the heater with time.

The sum of exchangeable cations was less than the CEC measured in MX-80 and Deponit CaN. The apparent decrease in the sum of exchangeable cations did not result from the decrease in CEC because the CEC was the same as the reference values. The discrepancy in the sum of exchangeable cations and CEC is probably related to methodological uncertainty in exchangeable cation extraction of calcareous and/or gypsiferous bentonites (MX-80 and Deponit $\mathrm{CaN}$ ) as discussed previously (Dohrmann \& Kaufhold, 2010; Dohrmann et al., 2012b).

The observed decrease in CBD-extractable Fe as a function of distance from the heater in Deponit CaN and Friedland clay could be explained by improvement in crystal order of Fe phases due to thermal effects.

Both this and previous studies (Svensson et al., 2011; Olsson et al., 2013) have shown that $\mathrm{Mg}$ was accumulated towards the heater. Interestingly, in this study, not only total and water-soluble $\mathrm{Mg}$, but also $\mathrm{CBD}$-extractable $\mathrm{Mg}$ appeared to have accumulated towards the heater. It was assumed that CBD extraction was capable of dissolving Mg-containing newly formed phases, e.g. Mg-hydroxides or Mg-sulfates. Note, however, that when compared to reference levels, the CBD-extractable $\mathrm{Mg}$ decreased significantly.

Mineralogical analysis indicated the accumulation of gypsum and dissolution of cristobalite, tridymite/ opal and feldspars near the heater. Such changes are generally in line with the chemical data. Dissolution of cristobalite has been observed in the ABM1 samples close to the Fe heater (Kaufhold et al., 2013). The reason for dissolution of cristobalite, but also of tridymite/opal and feldspars in this study might be related to elevated porewater $\mathrm{pH}$ that originated from corrosion of Fe (Dohrmann \& Kaufhold, 2014).

The comparison of chemical composition-based calculated mineralogical compositions (values in parenthesis in Table 1) with mineral contents gained from mineralogical analysis showed that the pyrite content was overestimated, and gypsum contents were underestimated in all materials. Moreover, the calcite contents were overestimated for MX-80. The reason for the discrepancy was assumed to result from uncertainties in both mineralogical and chemical analyses. For example, accessory mineral contents were close to the detection limit of XRD ( 1 wt.\%).

The appearance of a weak $d_{060}$ hump in the XRD patterns of clay minerals suggested that trioctahedral clay minerals might have been formed in samples in contact with the iron heater. Samples from ABM2 block 9 (Febex), much closer to the heater than the samples in the present study were analysed by Svensson (2015) who found more robust XRD evidence for the existence of trioctahedral clay minerals as well as supporting chemical and FTIR data which suggested the presence of Fe-saponite.

The reason for increased organic carbon content could not be explained. The source was probably not the lubricant used for compressing the blocks, because organic-carbon content increased uniformly in all ABM2 samples, not just at block edges (which showed elevated Mo and $\mathrm{Zn}$ contents and these do indicate an influence by the lubricant). Furthermore, the possibility of analytical error was also excluded as the control samples analysed at the same time showed no evidence of excess organic carbon. Thus, the increase in organic carbon content was thought to have resulted from artefact, i.e. contamination of samples during storage, in spite of keeping them vacuum packed during storage.

The observed decrease in swelling pressure of coredrilled samples of Friedland clay that was recovered after grinding and recompaction was in line with previous studies (Kumpulainen \& Kiviranta, 2011; Svensson et al., 2011). Note also that the swelling pressure of core-drilled samples of MX-80 and Deponit $\mathrm{CaN}$ did not decrease - at least by no more than observed previously in the ABM1 experiment (Kumpulainen \& Kiviranta, 2011; Svensson et al., 2011).

\section{CONCLUSIONS}

The chemical and mineralogical effects observed in the $\mathrm{ABM} 2$ test were more pronounced than those in the ABM1 test probably due to the longer duration of the test (5 y of heating in the ABM2 test compared to $2.5 \mathrm{y}$ in the ABM1 test). In ABM2, three types of chemical effects were recorded: uniform changes occurred in blocks, rising or falling trends in horizontal profiles of 
the blocks, and changes occurring only at the boundary with the iron heater.

Changes occurring uniformly in blocks might result from interactions with the Äspö groundwater, rising or falling trends in horizontal profiles might originate from thermal interactions, and changes at the boundary with the iron heater might result either from interactions with the iron heater or because of thermal effects.

Compared to the reference samples, the exchangeable cation populations changed uniformly in all blocks. Increases in water-soluble $\mathrm{Ca}, \mathrm{Mg}, \mathrm{K}$ and $\mathrm{SO}_{4}$, decreases in poorly crystalline $\mathrm{Fe}$ oxides, increase in the total amounts of $\mathrm{Mg}, \mathrm{Ca}, \mathrm{S}$ and decreases in the total amounts of $\mathrm{Na}$ and $\mathrm{K}$ were noted in horizontal profiles towards the heater. At the boundary with the heater, increase in $\mathrm{Fe}$ and decreases in the amounts of $\mathrm{Si}$ and $\mathrm{Al}$, the precipitation of gypsum and anhydrite, indications of the formation of trioctahedral clay minerals, and the dissolution of cristobalite and feldspars were observed. In addition, a decrease in the swelling pressure of core-drilled samples of Friedland clay was observed that was recovered after grinding and recompaction. No change in hydraulic conductivity was observed in any of the materials studied.

\section{ACKNOWLEDGEMENTS}

The authors acknowledge gratefully Posiva Oy for financing the work. Svensk Kärnbränslehantering $\mathrm{AB}$ and Clay Technology $\mathrm{AB}$ are thanked for providing the samples, and two anonymous reviewers are thanked for constructive comments which helped to improve the manuscript. The authors are very grateful to Noora Kanerva, Petriikka Karttunen and Nora Akhanoba from $\mathrm{B}+$ Tech $\mathrm{Oy}$ for their assistance with sampling and analysis.

\section{REFERENCES}

Åkesson M., Olsson S., Dueck A., Nilsson U., Karnland O., Kiviranta L., Kumpulainen S. \& Lindén J. (2012) Temperature buffer test, Hydro-mechanical and chemical/mineralogical characterizations. P-12-06. Svensk Kärnbränslehantering $\mathrm{AB} \quad$ (SKB), Stockholm, Sweden.

Ammann L., Bergaya F. \& Lagaly G. (2005) Determination of the cation exchange capacity of clays with copper complexes revisited. Clay Minerals, 40, 441-453.

Belyayeva N.I. (1967) Rapid method for the simultaneous determination of the exchange capacity and content of exchangeable cations in solonetzic soils. Soviet Soil Science, 1409-1413.

Dohrmann R. \& Kaufhold S. (2010) Determination of exchangeable calcium of calcareous and gypsiferous bentonites. Clays and Clay Minerals, 58, 79-88.

Dohrmann R. \& Kaufhold S. (2014) Cation exchange and mineral reactions observed in MX80 buffer samples of the Prototype repository in situ experiment in Äspö, Sweden. Clays and Clay Minerals, 62, 357-373.

Dohrmann R., Genske D., Karnland O., Kaufhold S., Kiviranta L., Olsson S., Plötze M., Sandén T., Sellin P., Svensson D. \& Valter M. (2012a) Interlaboratory CEC and exchangeable cation study of bentonite buffer materials: I. $\mathrm{Cu}$ (II)-triethylenetetramine method. Clays and Clay Minerals, 60, 162-175.

Dohrmann R., Genske D., Karnland O., Kaufhold S., Kiviranta L., Olsson S., Plötze M., Sandén T., Sellin P., Svensson D. \& Valter M. (2012b) Interlaboratory CEC and exchangeable cation study of bentonite buffer materials: II. Alternative methods. Clays and Clay Minerals, 60, 176-185.

Dohrmann R., Olsson S., Kaufhold S. \& Sellin P. (2013) Mineralogical investigations of the first package of the alternative buffer material test II. Exchangeable cation population rearrangement. Clay Minerals, 48, 215-233.

Drever J.I. (1973) The preparation of oriented clay mineral specimen for X-ray diffraction analysis by a filtermembrane peel technique. American Mineralogist, 58, 553-554.

Eng A., Nilsson U. \& Svensson D. (2007) Äspö Hard Rock Laboratory. Alternative Buffer Material. Installation report. SKB IPR-07-15. Svensk Kärnbränslehantering $\mathrm{AB} \quad(\mathrm{SKB})$, Stockholm, Sweden.

Jackson M.L. (1975) Soil Chemical Analysis - Advanced Course, $2^{\text {nd }}$ edition. Published by the author, Madison, Wisconsin, USA, 991 pp.

Karnland O., Olsson S., Dueck A., Birgersson M., Nilsson U., Hernan-Håkansson T., Pedersen K., Nilsson, S., Eriksen T.E. \& Rosborg B. (2009) Long-term test of buffer material at the Äspö Hard Rock Laboratory, LOT project, Final report on the A2 test parcel. TR-0929. Svensk Kärnbränslehantering AB (SKB), Stockholm, Sweden.

Kaufhold S., Dohrmann R., Sandén T., Sellin P. \& Svensson D. (2013) Mineralogical investigations of the first package of the alternative buffer material test I. Alteration of bentonites. Clay Minerals, 48, 199-213.

Kiviranta L. \& Kumpulainen S. (2011) Quality control and characterization of bentonite materials. Posiva WR 2011-84. Posiva Oy, Olkiluoto, Finland.

Kumpulainen S. \& Kiviranta L. (2010) Mineralogical and chemical characterization of various bentonite and smectite-rich clay materials. Posiva WR 2010-52. Posiva Oy, Olkiluoto, Finland. 
Kumpulainen S. \& Kiviranta L. (2011) Mineralogical, chemical and physical study of potential buffer and backfill materials from ABM test package 1. Posiva WR 2011-41. Posiva Oy, Olkiluoto, Finland.

Meier L.P \& Kahr G. (1999) Determination of the cation exchange capacity (CEC) of clay minerals using the complexes of copper(II) ion with triethylenetetramine and tetraethylenepentamine. Clays and Clay Minerals, 47, 386-388.

Moore D.M. \& Reynolds R.C. (1989) X-ray diffraction and the Identification and Analysis of Clay Minerals. Oxford University Press, New York.

Muurinen A. (2010) Studies on the chemical conditions and microstructure in package 1 of Alternative Buffer Materials Project (ABM) in Äspö. Posiva WR 201011. Posiva Oy, Olkiluoto, Finland.

Newman A.C.D. \& Brown G. (1987) The chemical constitution of clays. Pp. 1-128 in: Chemistry of Clays and Clay Minerals (A.C.D. Newman, editor). Mineralogical Society, Monograph no. 6. Longman Scientific \& Technical, Essex, England.
Olsson S., Jensen V., Johannesson L.-E., Hansen E., Karnland O., Kumpulainen S., Kiviranta L., Svensson D., Hansen S. \& Lindén J. (2013) Prototype repository. Hydro-mechanical, chemical and mineralogical characterization of the buffer and tunnel backfill material from the outer section of the Prototype Repository. TR13-21. Svensk Kärnbränslehantering $\mathrm{AB}$ (SKB), Stockholm, Sweden.

Svensk Kärnbränslehantering AB (2014) Äspö Hard Rock Laboratory, Annual Report 2013. TR-14-17, Svensk Kärnbränslehantering AB (SKB), Stockholm, Sweden. Svensson D. (2015) The Bentonite Barrier. Swelling Properties, Redox Chemistry and Mineral Evolution. Doctoral dissertation, Faculty of Engineering, Lund University, Sweden.

Svensson D., Dueck A., Nilsson U., Olsson S., Sandén T., Lydmark S., Jägerwall S., Pedersen K. \& Hansen S. (2011) Alternative buffer material. Status of the ongoing laboratory investigation of reference materials and test package 1. TR-11-06. Svensk Kärnbränslehantering $\mathrm{AB}$ (SKB), Stockholm, Sweden. 